\title{
PROLONGED SURVIVAL OF PATIENTS WITH PERIPHERAL T-CELL LYMPHOMA AFTER FIRST-LINE INTENSIVE SEQUENTIAL CHEMOTHERAPY WITH AUTOLOGOUS STEM CELL TRANSPLANTATION
}

\author{
Vit Prochazka ${ }^{a}$, Edgar Faber ${ }^{\mathrm{a}}$, Ludek Raida ${ }^{\mathrm{a}}$, Jana Vondrakova ${ }^{\mathrm{a}}$, \\ Ladislava Kucerova ${ }^{\mathrm{b}}$, Marie Jarosova ${ }^{\mathrm{a}}$, Karel Indrak ${ }^{\mathrm{a}}$, Tomas Papajik ${ }^{\mathrm{a}}$

\begin{abstract}
${ }^{a}$ Department of Hemato-Oncology, University Hospital, Olomouc, Czech Republic
${ }^{b}$ Department of Pathology, Faculty of Medicine and Dentistry, Palacky University, Olomouc, Czech Republic e-mail: vit.prochazka@fnol.cz
\end{abstract}

Received: April 30, 2008; Accepted: June 30, 2008

Key words: Peripheral T-cell lymphoma/PTCL/High-dose chemotherapy/Autologous transplantation/First line

Background: Nodal peripheral T-cell lymphomas (PTCLs) are infrequent subtypes of non-Hodgkin's lymphomas. The WHO classification recognizes three subgroups of nodal PTCL: peripheral T-cell lymphoma not otherwise specified (PTCL, NOS), anaplastic large cell lymphoma (ALCL) and angioimmunoblastic lymphoma (AIL). The clinical course is aggressive and despite multiagent chemotherapy, the median survival is about 2 years. Optimal first-line chemotherapy is not established and the role of high-dose therapy with autologous stem cell support is still controversial.

Aim: To analyze the long-term outcome of PTCL patients treated with intensive first-line chemotherapy with highdose therapy and autologous transplant consolidation.

Method: Sequential chemotherapy protocol consisting of 3 cycles of CHOEP-21-like regimen (PACEBO), 1 cycle of an ifosfamide and methotrexate-based regimen (IVAM) and a priming regimen with high-dose cytosine arabinoside (HAM). Consolidation was provided with myeloablative conditioning (BEAM 200) and autologous stem cell support. Eighty-four patients with aggressive high-risk lymphoma were treated with the sequential protocol from 2000 to 2007 in our institution. Here we report our experience with 18 patients with nodal PTCL (10 PTCL, NOS; 3 ALCL, ALKnegative; 2 ALCL, ALK-positive; 2 ALCL, unknown ALK status; 1 AIL).

Results: Eleven (61 \%) patients achieved complete remission, 3 (17\%) partial remission and 4 (22\%) patients failed the procedure. The overall response rate was $77.8 \%$. After a median follow-up of 25.7 months, nine patients relapsed or progressed (6 PTCL, NOS; 2 ALCL ALK-positive; 1 ALCL ALK-negative; median 14.1 months) and four patients died (lymphoma progression). The relapse was treated with allogeneic stem transplantation in one patient. The 2-year progression-free survival (PFS) was $52 \%$ (95\% CI, 0.27 to 0.76); the 2-year overall survival rate reached $71 \%$ (95\% CI, 0.47 to 0.95 ).

Conclusion: Our results show that intensive first-line chemotherapy with high-dose therapy and autologous transplant consolidation offers a chance for long-term survival in patients with chemosensitive PTCL.

\section{INTRODUCTION}

Peripheral T-cell lymphomas (PTCLs) are infrequent types of non-Hodgkin's lymphomas (NHLs). In Western countries they represent about $7 \%$ of NHLs ${ }^{1,2}$. The incidence of nodal T-cell lymphomas based on the data from the Czech Lymphoma Study Group (CLSG) registry is $6 \%$ (211 out of 3518 patients) $)^{3}$. The World Health Organization (WHO) classification recognizes three subgroups of nodal PTCLs: peripheral T-cell lymphoma, not otherwise specified (PTCL, NOS), anaplastic large cell lymphoma (ALCL) and angioimmunoblastic lymphoma (AIL $)^{4}$. Current conventional treatment modalities do not dramatically improve the outcome of patients and 5-year overall survival still remains between $30 \%$ and $35 \%$ using standard chemotherapy with second- and third-generation regimens ${ }^{5,6,7}$. The role and timing of high-dose therapy with autologous stem cell support (ASCT) remains unclear some studies have confirmed the survival advantage of
ASCT $^{8,9}$ while others produced inconsistent results ${ }^{10,11}$. Data from the Czech national registry of (autologous) hematopoietic stem cell transplantations and the CLSG database show an overall survival (OS) of 3 years in $74 \%$ of PTCL patients while conventionally treated patients have a median overall survival of as few as 33 months $^{12}$.

The objective of our retrospective single-center study was to analyze the treatment efficacy of a novel intensive first-line chemotherapy protocol with consolidation with high-dose therapy and autologous stem cell transplantation in unselected patients with nodal PTCL.

\section{PATIENTS AND METHODS}

Here we report our experience with 18 patients with nodal PTCL (10 PTCL, NOS; 3 ALCL, ALK-negative; 2 ALCL, ALK-positive; 2 ALCL, unknown ALK status; 1 AIL) who were diagnosed in our center between the 
Table 1. Patient baseline clinical characteristics.

$$
(n=18)
$$

\begin{tabular}{|l|c|}
\hline Sex (male-to-female ratio) & $2: 1$ \\
\hline Median age (range) & 59 years $(29-64)$ \\
\hline Advanced disease stage (III + IV) & 13 patients $(72 \%)$ \\
\hline Extranodal involvement & 13 patients $(72 \%)$ \\
\hline Bone marrow involvement & 5 patients $(27.8 \%)$ \\
\hline $\begin{array}{l}\text { Elevated lactate } \\
\text { dehydrogenase level }\end{array}$ & 4 patients $(22 \%)$ \\
\hline IPI score (0-1 vs. $\geq 2)$ & 5 vs. 13 patients \\
\hline Median follow-up & 25.7 months \\
\hline
\end{tabular}

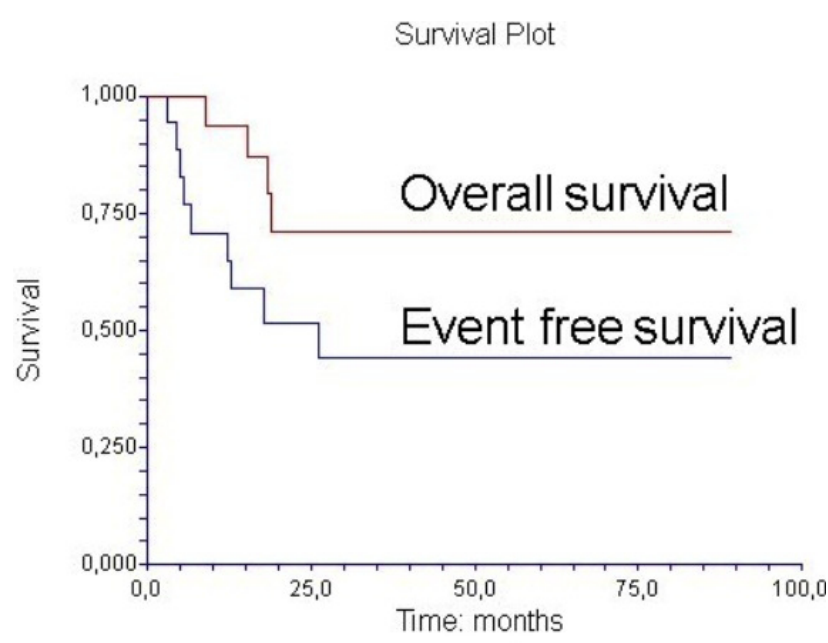

Fig. 1. Survival curves of 18 PTCL patients.

years 2000 and 2007. All biopsies were reviewed by a reference pathologist and final diagnoses were made in compliance with the published WHO classification of lymphoid tumours ${ }^{4}$. The median age at diagnosis was 43 years, 17 patients underwent the protocol as first-line therapy and one as salvage therapy. Twelve patients received first-line high-dose therapy and autologous transplant consolidation; two patients were consolidated with allogeneic stem cell transplantation with reduced-intensity conditioning.

\section{Treatment strategy}

The sequential chemotherapy protocol consists of 3 cycles of CHOEP-21-like regimen (PACEBO), 1 cycle of an ifosfamide and methotrexate-based regimen (IVAM) and a priming regimen with high-dose cytosine arabinoside (HAM). Consolidation is provided with myeloablative conditioning (BEAM 200) and autologous stem cell support. A total of 84 patients with aggressive high-risk lymphoma were treated with this sequential protocol from 2000 to 2007 in our institution.
The PACEBO regimen was administered as follows: doxorubicin $40 \mathrm{mg} / \mathrm{m}^{2}$ intravenously day 1 , cyclophosphamide $850 \mathrm{mg} / \mathrm{m}^{2}$ intravenously day 1 , etoposide $200 \mathrm{mg} / \mathrm{m}^{2}$ intravenously day 1 , bleomycin $10 \mathrm{mg} / \mathrm{m}^{2}$ intravenously day 8 , vincristine $1.4 \mathrm{mg} / \mathrm{m}^{2}$ (maximum $2.0 \mathrm{mg}$ ) intravenously day 8 and prednisone $40 \mathrm{mg} / \mathrm{m}^{2}$ orally days 1 to 14 . The IVAM regimen consisted of ifosfamide $1500 \mathrm{mg} / \mathrm{m}^{2}$ intravenously days 1 to 5 , etoposide $150 \mathrm{mg} / \mathrm{m}^{2}$ intravenously day 1 to 3 , cytosine arabinoside $100 \mathrm{mg} / \mathrm{m}^{2}$ intravenously day 1 to 3 , methotrexate $3 \mathrm{~g} / \mathrm{m}^{2}$ intravenously day 5 , mesna prophylaxis $1200 \mathrm{mg}$ intravenously days 1 to 5 , leucovorin rescue $25 \mathrm{mg} / \mathrm{m}^{2}$ intravenously from day $6 / 7$ until the plasma methotrexate level was below $0.05 \mu \mathrm{mol} / 1$. The HAM regimen was administered as follows: cytosine arabinoside $2 \mathrm{~g} / \mathrm{m}^{2}$ twice daily intravenously days 1 and 2, mitoxantrone $10 \mathrm{mg} / \mathrm{m}^{2}$ days 2 and 3. Stem cell mobilization was performed with $12 \mu \mathrm{g} / \mathrm{kg}$ of filgrastim given subcutaneously twice daily. The BEAM 200 conditioning regimen dosage was standard as previously published.

The treatment responses - complete response (CR), unconfirmed complete response ( $\mathrm{uCR}$ ), partial response (PR), stable disease and progressive disease - were defined according to the International Workshop NHL Response Criteria published by Cheson et $\mathrm{al}^{19}$.

Statistical methods. Our data were analyzed using the Statistical Package for the Social Sciences (SPSS) ${ }^{20}$. Overall survival (OS) was defined as the time from first treatment to the date of last follow-up examination (censored) or the date of death (event) from any cause. Progression free survival (PFS) was defined as the date of first treatment to the date of documented disease progression or death (event) or the date of last follow-up examination (censored). The Kaplan-Meier method ${ }^{21}$ was used to calculate survival probabilities. The log-rank test was used to compare differences in survival times between patient subgroups. The significance level was set at a $\mathrm{p}=$ 0.05; 2-tailed tests were used in all calculations.

The EMBASE and PubMed databases were searched for literature reviews.

\section{RESULTS}

We analyzed the data of the 18 patients. The baseline clinical parameters are summarized in Table 1 . The median age was 59 years (range, 29-64 years), there was a male preponderance (male-to-female ratio $2: 1$ ). Most of the patients $(n=13,72 \%)$ had advanced disease of clinical stages III and IV with extranodal lymphoma involvement. Most frequently, bone marrow was involved (27.8 \%). B symptoms were present in half of the patients. More than three quarters of the patients had an ambulatory performance status (PS $0-1, \mathrm{n}=15,83.4 \%$ ). Lactate dehydrogenase (LDH) levels were elevated in 4 cases (>1 X normal value). The International Prognostic Index (IPI) ${ }^{13,14}$ score was available in all patients; 5 patients were classified as low risk (0-1), 5 as low-intermediate risk 
(IPI 2) and 8 as high-intermediate or high risk (IPI $\geq 3$ ). The toxicity of the treatment protocol was tolerable. Most commonly, hematologic toxicity and infections of grades III-IV according to the NCI CTC were observed. No treatment toxicity- or transplant-related death occurred. No persistent treatment-related disability or severe organ dysfunction were observed. So far, no secondary malignancies have occurred.

\section{Analysis of response and survival}

The overall CR rate was $61 \%(n=11), P R$ rate $17 \%$ $(\mathrm{n}=3)$ and 4 patients $(22 \%)$ had stable or progressive disease after first-line treatment. After a median followup of 25.7 months, nine patients relapsed or progressed (6 PTCL, NOS; 2 ALCL ALK-positive; 1 ALCL ALKnegative; median 14.1 months) and four patients died (lymphoma progression). Nine patients are still in CR. In one patient, the relapse was treated with allogeneic stem cell transplantation. The 2-year progression-free survival (PFS) was $52 \%$ (95\% CI, 0.27 to 0.76$)$; the overall survival rate reached $71 \%$ (95\% CI, 0.47 to 0.95 ).

\section{DISCUSSION AND CONCLUSION}

PTCLs still represent a heterogeneous group of aggressive lymphomas with disappointing treatment results. In most cases, conventional chemotherapy either is ineffective or leads only to response with limited duration. Gisselbrecht et al. reported a 5-year OS of $35 \%$ in PTCL patients ${ }^{7}$, Escalón et al. published even worse results both in patients treated intensively or with the CHOP regimen (3-year OS of $49 \%$ and $43 \%$, respectively) ${ }^{24}$. The appropriate dose intensity of chemotherapy and the role of high-dose therapy with ASCT were unclear due to the heterogeneity of the studied sample and frequent inclusion of anaplastic PTCL or B-cell lymphoma subtypes ${ }^{14,24}$.

Recently, numerous clinical studies have been published that show variable effects of intensive induction therapy followed by consolidation with high-dose chemotherapy and autologous stem cell transplantation. A large retrospective study carried out by the Lymphoma Working Party of the European Group for Blood and Marrow Transplantation have confirmed the benefit of this treatment modality in patients with AIL, especially if CR was achieved after induction treatment (OS $67 \%$ at 24 months and $58 \%$ at 48 months) (ref. ${ }^{27}$ ). In contrast, a prospective study by Mercadal et al. showed no clear benefit of aggressive treatment approach in first-line therapy - the use of the high-dose CHOP regimen alternating with the platinum-based ESHAP regimen is associated with significant toxicity and no real increase in the rate of complete remission $^{28}$. Rodríguez reported the effect of early ICE salvage therapy and autologous stem cell transplantation in high-risk PTCL patients, with gallium-positive scan after 3 cycles of treatment with the megaCHOP protocol and an optimistic OS at 3 years of $73 \%\left(\right.$ ref. $\left.^{29}\right)$. Similarly favorable results are those in Rodríguez's retrospective analysis of AIL patients with a 3-year OS of $60 \%$ (ref. $^{30}$ ).
According to our experience, a significant number of patients with nodal PTCL may benefit from the sequential treatment protocol and early consolidation with autologous stem cell transplantation. In our group, the overall response rate reached $78 \%$ (CR rate $61 \%$, PR rate $17 \%)$. The procedure failed in a quarter of the patients. After initial treatment, relapse or lymphoma progression occurred in half of the patients, with a median of 14.1 months. Paradoxically, treatment failed in both patients with ALK-positive ALCL. The 2-year progression-free survival (PFS) was $52 \%$; the 2-year overall survival rate reached $71 \%$. The toxicity of the sequential protocol was tolerable. Despite the administration of lower doses of cyclophosphamides and anthracyclines, and the absent platinum-based regimen, the protocol results in treatment outcomes comparable to those achieved by the $\mathrm{MegaCHOP/ESHAP} \mathrm{regimens.}$

To conclude, the treatment approach to younger patients with nodal PTCL is not unified. The current first-line treatment procedures range from the classical CHOP schemes, through the MegaCHOP/ESHAP/ICE intensive toxic regimens, to high-dose chemotherapy with autologous stem cell transplantation. The administration of our novel intensive first-line sequential chemotherapy protocol with consolidation with high-dose therapy and autologous stem cell transplantation is a safe and effective treatment modality in patients with nodal PTCL. In about half of the patient population, intensive chemotherapy with autologous stem cell transplantation offers a chance for long-term survival and may lead to improved quality of treatment response or provide time for finding a donor for allogeneic transplantation ${ }^{11}$. Future advances in treating these patients will not be possible without designing prospective studies, introducing immunochemotherapy ${ }^{26}$ and implementing new prognostic schemes ${ }^{16,17}$ and PET restaging.

\section{ACKNOWLEDGEMENT}

Supported by the grant of the Ministry of Education of the Czech Republic (MSM 6198959205).

\section{REFERENCES}

1. Rüdiger T, Weisenburger DD, Anderson JR, Armitage JO, Diebold J, MacLennan KA, Nathwani BN, Ullrich F, Müller-Hermelink. (2002) Peripheral T-cell lymphoma (excluding anaplastic largecell lymphoma): results from the Non-Hodgkin's Lymphoma Classification Project. Ann Oncol 13, 140-149.

2. Morton LM, Wang SS, Devesa SS, Hartge P, Weisenburger DD and Linet MS. (2006) Lymphoma incidence patterns by WHO subtype in the United States, 1992-2001. Blood 107 (1), 265-276.

3. Trněný M, Vášová I, Pytlík R, Belada D, et al. (2007) The NonHodgkin's lymphoma subtypes distribution and survival in Czech Republic. Klinická onkologie, 20, 341 - 348

4. Banks PM, Warnke RA. Mature T-cell and NK-cell neoplasms. In: Jaffe ES, Harris NL, Stein H, Vardiman JW (eds): World Health Organization Classification of Tumours: Pathology and Genetics of Tumours of Hematopoetic and Lymphoid Tissues. Lyon, France: IARC Press, 2001. p. 189-230. 
5. Savage KJ. Aggressive Peripheral T-Cell Lymphomas (Specified and Unspecified Types). In: American Society of Hematology Educational Book, USA: American Society of Hematology, 2005. p. 267-277

6. Coiffier B, Brousse N, Peuchmaur M, et al. (1990) Peripheral T-cell lymphomas have a worse prognosis than B-cell lymphomas: a prospective study of 361 immunophenotyped patients treated with LNH84 regimen. J Clin Oncol 9, 45-50.

7. Gisselbrecht C, Gaulard P, Lepage E, Coiffier B, Briere J, Haioun C, Cazals-Hatem D, Bosly X, Xerri L, Tilly H, Berger F, Bouhabdallah R, Diebold J. (1998) Prognostic significance of T-cell phenotype in aggressive non-Hodgkin's lymphomas. Blood 92, 76-82.

8. Haioun C, Lepage E, Gisselbrecht C, Bastion Y, Coiffier B, Brice P, Bosly A, Dupriez B, Nouvel C, Tilly H, Lederlin P, Biron P, Briere J, Gaulard P, Reyes F. (1997) Benefit of autologous bone marrow transplantation over sequential chemotherapy in poor-risk aggressive non-Hodgkin's lymphoma: updated results of the prospective study LNH87-2. Groupe d'Etude del Lymphomes de l'Adulte. J Clin Oncol 15, 1131-1137.

9. Rodriguez J, Caballero MD, Gutierrez A, Marin J, Lahuerta JJ, Sureda A, Carreras E, Leon A, Arranz R, Fernandez de Sevilla A, Zuazu J, Garcia-Larana J, Rifon J, Varela R, Gandarillas M, SanMiguel J, Conde E. (2003) High-dose chemotherapy and autologous stem cell transplantation in peripheral T-cell lymphoma: the GEL-TAMO experience. Ann Oncol 14, 1768-1775.

10. Corradini P, Tarella C, Zallio F, Dodero A, Zanni M, Valagussa P, Gianni AM, Rambaldi A, Barbui T, Cortelazzo S. (2006) Longterm follow-up of patients with peripheral T-cell lymphomas treated up-front with high-dose chemotherapy followed by autologous stem cell transplantation. Leukemia 20 1533-8.

11. Corradini P, Dodero A, Zallio F, Caracciolo D, Casini M, Bregni M, Narni F, Patriarca F, Boccardo M, Benedetti F, Rambaldi A, Gianni A, Tarella C. (2004) Graft-versus-lymphoma effect in relapsed peripheral T-cell non-Hodgkin's lymphomas after reducedintensity conditioning followed by allogeneic transplantation of hematopoietic cells. J Clin Oncol 22, 2172-2176.

12. Prochazka V, Trneny M, Pytlik R, Vasova I, et al. (2007) Peripheral T-cell lymphoma, unspecified--the analysis of the data from the Czech Lymphoma Study Group (CLSG) registry. Biomed Pap Med Fac Univ Palacky Olomouc Czech Repub. 151(1), 103-7.

13. Tarella C, Caracciolo D, Ladetto M, Zallio F, Cuttica A, Ricca I, Gavarotti P, Bergui L, Corradini P, Pileri A. (2000) 11-yr followup of 184 non- Hodgkin's lymphoma (NHL) patients treated with high-dose sequential (HDS) chemotherapy and autograft: highest response and best outcome in germinal-center derived subtypes [abstract. Blood 96, 769a

14. Mounier N, Gisselbrecht C, Briere J, Haioun C, Feugier P, Offner F, Recher C, Stamatoullas A, Morschhauser F, Macro M, Thieblemont C, Sonet A, Fabiani B, Reyes F. (2004) Prognostic factors in patients with aggressive non-Hodgkin's lymphoma treated by front-line autotransplantation after complete remission: a cohort study by the Groupe d'Etude del Lymphomes de l'Adulte. J Clin Oncol 22, 2826-2834.

15. Shipp M, Harrington D, Chairpersons et al. (1993) A predictive model for aggressive non- Hodgkin's lymphoma: The International NHL Prognostic Factors Project. N Engl J Med 329, 987-994.

16. Sonnen R, Schmidt WP, Müller-Hermelink HK, Schmitz N. (2005) The International Prognostic Index determines the outcome of patients with nodal mature T-cell lymphomas. Br J Haematol 129, 366-372.

17. Gallamini A, Stelitano C, Calvi R, Bellei M, Mattei D, Vitolo U, Morabito F, Martelli M, Brusamolino E, Iannitto E, Zaja F,
Cortelazzo S, Rigacci L, Devizzi L, Todeschini G, Santini G, Brugiatelli M, Federico M. (2004) Peripheral T-cell lymphoma unspecified (PTCL-U): a new prognostic model from a retrospective multicentric study. Blood 103, 2474-2479.

18. Went P, Agostinelli C, Gallamini A, Piccaluga PP, Ascani S, Sabattini E, Bacci F, Falini B, Motta T, Paulli M, Artusi T, Piccioli M, Zinzani PL, Pileri SA. (2006) Marker expression in peripheral T-cell lymphoma: a proposed clinical-pathologic score. J Clin Oncol 24, 2472-2479.

19. Cheson BD, Horning SJ, Coiffier B, Shipp MA, Fisher RI, Connors JM, Lister TA, Vose J, Grillo-Lopez A, Hagenbeek A, Cabanillas F, Klippensten D, Hiddemann W, Castellino R, Harris NL, Armitage JO, Carter W, Hoppe R, Canellos GP. (1999) Report of an International Workshop to standardize Response Criteria for Non-Hodgkin's Lymphomas. J Clin Oncol 17, 1244-1253.

20. Nie HH, Hadlai H, Jenkins JG, Steinbrenner K, Bent DH. (1979) SPSS (Statistical Package for the Social Sciences). New York, NY: McGraw-Hill

21. Kaplan EL, Meier P. (1958) Non parametric estimation from incomplete observation. JAMA 53, 457-481.

22. Geissinger E, Bonzheim I, Krenacs L, Roth S, Reimer P, Wilhelm M, Müller-Hermelink H, Rüdiger T. (2006) Nodal peripheral T-cell lymphomas correspond to distinct mature T-cell populations. J Pathol 210, 172-180.

23. Ballester B, Ramuz O, Gisselbrecht C, Doucet G, Loi L, Loriod B, Bertucci F, Bouabdallah R, Devilard E, Carbuccia N, Mozziconacci MJ, Birnbaum D, Brousset P, Berger F, Salles G, Briere J, Houlgatte R, Gaulard P, Xerri L. (2005) Gene expression profiling identifies molecular subgroups among nodal peripheral T-cell lymphomas. Oncogene 14, 1560-70

24. Escalon MP, Liu NS, Yang Y, Hess M, Walker PL, Smith TL, Dang NH. (2005) Prognostic factors and treatment of patients with T-cell non-Hodgkin lymphoma. Cancer 103, 2091-8.

25. Trněný M, Fekete S, Walewski J, Ladická M, Kreuzbauer G, Skacel T. A retrospective study to assess relative dose intensities in patients with lymphoma in Central European countries. In: Haematologica 2006; 91(supplement 1), 11th Congress of the European Hematology Association, Amsterdam, Netherlands, 1518 June 2006.

26. Ravandi F, Keating M. Alemtuzumab in T-cell malignances. In: Hillmen P, Witzig TE. Immunotherapy of lymphoid malignancies. Oxford: Atlas Medical Publishing, 2005. p.189-196.

27. Kyriakou Ch, Canals C, Goldstone A et al. (2008) High-dose therapy and autologous stem-cell transplantation in angioimmunoblastic lymphoma: complete remission at transplantation is a major determinant of outcome - Lymphoma Working Party of European Group for Blood and Marrow Transplantation. J Clin Oncol 26, 218-224.

28. Mercadal S, Briones J, Xicoy B, Pedro C et al. (2008) Intensive chemotherapy (high-dose CHOP/ESHAP regimen) with autologous stem-cell transplantation in previously untreated patients with peripheral T-cell lymphoma. Ann Oncol Feb 2008

29. Rodríguez J, Conde E, Gutiérrez A, Arranz R, León A et al. (2007) Frontline autologous stem cell transplantation in high-risk peripheral T-cell lymphoma: a prospective study from The Gel-Tamo Study Group. Eur J Haematol 79, 32-8.

30. Rodríguez J, Conde E, Gutiérrez A, Arranz R et al. (2007) Prolonged survival of patients with angioimmunoblastic T-cell lymphoma after high-dose chemotherapy and autologous stem cell transplantation: the GELTAMO experience. Eur J Haematol 78, 290-296. 